\title{
A Comparative Study on Daylight Performance Assessment of Light Shelves Based on Inclination
}

\author{
Sadaf Noshin ${ }^{1 a}$, Humaira Kanwal ${ }^{1 b}$, Abrar Ahmad ${ }^{2}$ \\ RECEIVED ON 05.03.2019, ACCEPTED ON 26.07.2019
}

\begin{abstract}
Energy consumption of lighting can be reduced by using different daylight control strategies. The rise in environmental distresses requires the necessity of natural light control systems. Light shelf is considered as excellent lighting control scheme that provides great lighting production and inexpensive prospect via entering the daylight inside the space. The aims of this study shows that the daylight efficiency and visual productivity are affected by the design parameters of light shelf such as its angle, location and height. In this research, Autodesk Ecotect 2011 is used for the daylight simulation of summer solstice and winter solstice days under overcast sky conditions on a nominated theoretical study space of an institutional building. Daylight simulation is carried out to evaluate the illuminance requirement within the selected space and analysis is also executed on the model with selected categories of light shelves including different positions, heights and angles. The acquired data is then exported on Radiance software intended for complete day-light investigation. The results of this research shows that external light shelf at a height of $7^{\prime}$ and an angle of $20^{\circ}$ is the most appropriate choice in prevailing the glare and it also enhanced the illuminance level to11.5\% in $21^{\text {st }} \mathrm{June}$ and $10.6 \%$ in $21^{\text {st }}$ December as compared to without light shelves. Furthermore, the shaded range is decreased by the rise in the angle of Light shelf which has a tendency to increase the inside average lighting. Hence, significant consideration should be given to the height and position of light shelves, since it has a superior effect on light shelf performance.
\end{abstract}

Keywords: Autodesk Ecotect 2011, Radiance, Daylighting Strategies, Light Shelf, OvercastSky, Glare, Illuminance.

\section{INTRODUCTION}

$\mathrm{E}$ nvironmental enhancements require building positioning as a dynamic component of inactive solar strategy of all scheduling activities [1]. Due to increase in global warming and decrease in energy reserves, it is necessary to reduce energy usage for all the buildings [2]. International Energy Agency, an American organization has stated that artificial lighting constitutes $18 \%$ of overall energy consumption of building zone. This consumption in illumination is continuously increasing throughout the year [3].
Energy efficiency is required to maintain a comfortable environment within the building but it is reduced due to electricity utilization for artificial lights and cooling equipment's [4]. It is beneficial to maintain a relaxed interior atmosphere especially in educational buildings in exchange for sufficient energy consumption [5,6]. A suitable energy efficient design is required to achieve the goal, which provides superlative environmental situations to accomplish visual relief and reduce glare by consuming minimum energy [7]. Different types of lighting schemes are used to reduce the energy consumption of any recognized equipment. It is observed that artificial lights are consumed $1 / 3^{\text {rd }}$ of electric power on the

\footnotetext{
${ }^{1}$ Department of Technology, The University of Lahore, Lahore, Pakistan. Email: ${ }^{a}$ sadaf.noshin@tech.uol.edu.pk (Corresponding Author), bhumaira.kanwal@tech.uol.edu.pk ${ }^{2}$ Deputy Manager Substation Design, NTDC Department, Lahore, Pakistan. Email: Abrar.engr@ntdc.com.pk

This is an open access article published by Mehran University of Engineering and Technology, Jamshoro under CC BY 4.0 International License.
} 
commercial sites [8-10]. Every building vendors can utilize least amount of electric power through artificial lights and save their money. For this purpose, they endeavor to operate effective systems for monitoring light to lessen their energy utilization $[9,11]$.

The consumers' visual relaxation and energy performance is enhanced deprived of luxurious fixing and operative rate through daylighting. On the other hand, natural light may produce difficulties due to brightness particularly at working plane or some spaces where visual comfort is required. A number of protection strategies are used to regulate glaring issues and lessen the sweatiness through daylight gains [2]. $60 \%$ of energy ingestion of a structure is reduced through adjusting natural light and quality of daylight is improved in the vicinity of the working areas [12]. Advanced daylighting strategies like Light pipe systems, prismatic glazing, and Mirror system are implemented to minimize the energy depletion by enhancing the circulation of day light within the structure [13-15]. In present-day additional schemes for example perpendicular and flat louvers, projections, and light shelves are established [16].

\section{CONCEPTION OF LIGHT SHELF SYSTEM}

Light shelves are considered one of the most effective way to overcome energy consumption problems through artificial lighting within a building $[10,16]$. A light shelf is an efficient daylighting strategy and shading device that improves the inferiority of interior illuminance atmosphere through obstructive continuous daylighting, thus resolving glaring difficulties inside the building. Consequently, the internal lighting and temperature can be improved by dual properties such as instantaneous illumination and screening of a light shelf. The energy consumption through light shelf can be achieved by reflecting the daylight deeply within the space $[3,12,17]$ which is given in Fig. 1.

It is a passive component of architecture that assists the dual purpose of reflecting day-light and providing shade [18-21]. The main part of light shelf is the horizontal component that is placed on the external side or on both sides of window façade. It may be provided above the eyelevel such that by dividing the window height into two portions; the $2 / 3^{\text {rd }}$ part of the window is below the light shelf that redirects the natural light inside the space and $1 / 3^{\text {rd }}$ part of window is below the shelf that permits the uninterrupted infiltration of day-light [22-24]. The major aim of this research is to reduce the glare adjacent to the window areas by adding the day light strategies for example light shelves with different design parameters such as height, position and angles.



Fig. 1: Conception of the Light Shelf [17]

\section{METHODOLOGY}

The performance of the proposed daylighting strategies are evaluated by using weather simulation tools [22-24]. The research process for the daylight evaluation of inclined Light shelves is shown in Fig. 2. The Auto-Desk Ecotect 2011 is a weather investigation device that is used to check the properties of different light shelves (4'-6"x2') for the designated study space having a measurement of (50'$\left.0 " x 30 '-0 " x 15^{\prime}\right)$. There are five large windows having dimensions of (4'-6"x7') and the sill height is (36") provided on south facing facade of the hypothetical study space. Daylight simulations is carried out under overcast sky condition on $21^{\text {st }}$ June and $21^{\text {st }}$ December at $2.00 \mathrm{pm}$ by considering two different types of light shelves including External and Internal at a height of $7^{\prime}$ and $8^{\prime}$ from the floor level at different angles of $0^{\circ}, 10^{\circ}, 20^{\circ}$. 
Evaluate the illuminance requirement within the Study space

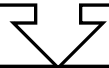

Model is prepared without light shelves and with different types of light shelves(External \& Internal) at an angles of $0^{\circ}, 10^{\circ}, 20^{\circ}$.

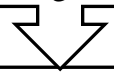

Ecotect software is used for the daylight analysis on the investigated model



Export data on Radiance software for detailed daylight analysis and analyze the illuminance data



Compare the Illuminance values of the Investigated model without and with light Shelves at different position, heights and angles.

Fig.2: Flow Chart of Research Methodology

\section{RESULTS AND DISCUSSIONS}

All the illuminance data is attained over and done with daylight analysis on the weather analysis tools.

\subsection{Simulations process and Day Light Analysis}

A theoretical study space having a dimensions of (30'$\left.0 " x 50 '-0 " x 15^{\prime}\right)$ is selected for the Ecotect analysis which is presented in Fig. 3 and features are specified in Table 1 .

\begin{tabular}{|c|c|c|}
\hline \multicolumn{3}{|c|}{ Table 1: Features of Study Space } \\
\hline No. & Parameters & Dimensions \\
\hline 1. & Floor area & $1500 \mathrm{ft}^{2}$ \\
\hline 2. & Fenestration Area & $31.5 \mathrm{ft}^{2}$ \\
\hline 3. & Single light shelf area & $9 \mathrm{ft}^{2}$ \\
\hline 4. & Window sill height & $3 \mathrm{ft}$. \\
\hline 5. & Working plane level & $3 \mathrm{ft}$. \\
\hline 6. & Ceiling height & $15 \mathrm{ft}$. \\
\hline
\end{tabular}

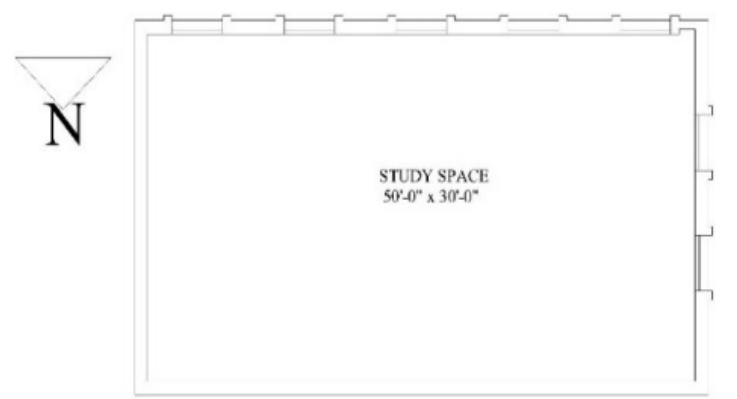

Fig. 3: Architectural Plan of Study Space
Light shelves are provided at a height of 7' and 8' from the floor level on the south facing windows at an angles of $0^{\circ}, 10^{\circ}$ and $20^{\circ}$. External and internal are two different positions of light shelf planned for the simulation procedure. Ecotect examination comprises the location of analysis grid at 36" from the floor level. Ecotect Investigation parameters for simulation are showing in Table 2.

\begin{tabular}{|c|c|}
\hline \multicolumn{2}{|c|}{ Table 2: Ecotect Investigation Parameters } \\
\hline Location & Pakistan, Lahore \\
\hline Date and Time & $21^{\text {st }}$ June and $21^{\text {st }}$ December, \\
& $2: 00 \mathrm{pm}$ \\
\hline Sky Illuminance & 9000 Lux (Derived from \\
& Model Latitude) \\
\hline Sky Condition & Overcast Sky \\
\hline Accuracy & Medium \\
\hline Type & Illuminance (Lux) \\
\hline
\end{tabular}

Several types of materials are allocated to the model of study space for simulation process. A list of constituents, particular ingredients, and the relevant reflectance values that are used in the simulation procedure are given in Table 3.

\begin{tabular}{|c|c|c|c|}
\hline \multicolumn{4}{|c|}{ Table 3: Elements, Assigned Materials, and Reflectance } \\
values
\end{tabular}

Daylight Investigation on Autodesk Ecotect 2011 is performed under overcast sky condition on $21^{\text {st }}$ June and $21^{\text {st }}$ December and the results are transferred to Radiance for comprehensive day-light assessment. Formerly, the acquired data from Radiance was brought to Ecotect Analysis so as to the Illuminance values are noticeably presented on analysis grid as shown in Fig. 4(a-b).

The same simulation procedure is reiterated for all types of light shelves at different angles and the obtained average illuminance values on $21^{\text {st }}$ June and $21^{\text {st }}$ December for the hypothetical study space is given in Table 4.

By considering the values in Table 4, it is observed that the study space without light shelve has greater Illuminance values 785 and 470 Lux for the months of June and December correspondingly, as compared to 


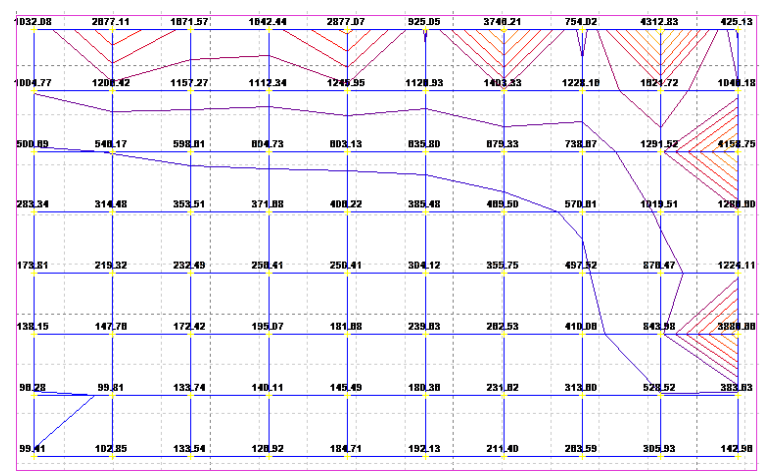

(a) Illuminance values on the analysis grid in the month of June

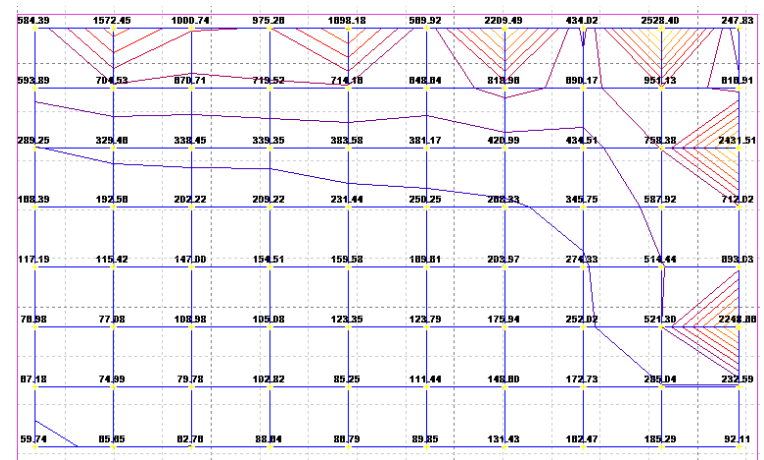

(b) Illuminance values on the analysis grid In the month of December

Fig. 4. Illuminance values on the analysis grid (without light Shelves)

\begin{tabular}{|c|c|c|c|c|c|c|}
\hline \multicolumn{7}{|c|}{ Table 4. Average illuminance values } \\
\hline \multirow[b]{2}{*}{ No. } & \multirow{2}{*}{$\begin{array}{l}\text { Date } \\
\text { and } \\
\text { Month }\end{array}$} & \multirow{2}{*}{$\begin{array}{l}\text { Types of } \\
\text { Light } \\
\text { Shelf }\end{array}$} & \multicolumn{4}{|c|}{$\begin{array}{c}\text { Average Illuminance Values } \\
\text { (Lux) }\end{array}$} \\
\hline & & & $0^{\circ}$ & $10^{\circ}$ & $20^{\circ}$ & $\begin{array}{l}\text { Without } \\
\text { Light } \\
\text { Shelves }\end{array}$ \\
\hline 1. & \multirow{4}{*}{$\begin{array}{l}21^{\text {st }} \\
\text { June }\end{array}$} & $\begin{array}{l}\text { External } \\
\left(7^{\prime}\right)\end{array}$ & 678 & 682 & 695 & \multirow{4}{*}{785} \\
\hline 2. & & $\begin{array}{l}\text { Internal } \\
\left(7^{\prime}\right)\end{array}$ & 712 & 735 & 750 & \\
\hline 3. & & $\begin{array}{c}\text { External } \\
\left(8^{\prime}\right)\end{array}$ & 680 & 694 & 702 & \\
\hline 4. & & $\begin{array}{c}\text { Internal } \\
\left(8^{\prime}\right)\end{array}$ & 720 & 744 & 763 & \\
\hline 5. & \multirow{4}{*}{$\begin{array}{l}21^{\text {st }} \\
\text { Dec. }\end{array}$} & $\begin{array}{c}\text { External } \\
\left(7^{\prime}\right)\end{array}$ & 396 & 410 & 428 & \multirow{4}{*}{470} \\
\hline 6. & & $\begin{array}{l}\text { Internal } \\
\left(7^{\prime}\right)\end{array}$ & 417 & 435 & 449 & \\
\hline 7. & & $\begin{array}{c}\text { External } \\
\left(8^{\prime}\right)\end{array}$ & 400 & 416 & 436 & \\
\hline 8. & & $\begin{array}{c}\text { Internal } \\
\left(8^{\prime}\right)\end{array}$ & 428 & 437 & 456 & \\
\hline
\end{tabular}

external and internal light shelves with different angles, therefore the day light level or glaring problems are extreme. The excellence and extent of natural light is enhanced by providing the light shelves on the south facing facade and glaring difficulties are also overcome. From the above results it is also observed that the amount of natural light inside the study space is improved by enlarging the angle of the light shelf and as a result artificial lighting energy is conserved. In case of external light shelf at a height of $7^{\prime}$ at an angle of $20^{\circ}$ the daylight level is increased to nearly $11.5 \%$ in $21^{\text {st }}$ June and $10.6 \%$ in $21^{\text {st }}$ December as compared to without light shelves. The illuminance levels are more concentrated when internal light shelves at a height of 7' and 8' are used and generate conspicuous trouble near the window areas on the working plane level. As the height of light shelf is increased from the floor level, drop in daylight level is enlarged which is correlated to preceding study [15]. For the purpose of energy saving the light shelf during winter is removed [22].

\section{CONCLUSIONS}

The Day-light investigation implemented on various light shelves in the months of June and December under over-cast sky situations, presented a reduction in day light levels that is similar to other results of correlated explores. It is significantly observed that exterior light shelves work as shading component i.e. used to inhibit the sunlight dropping openly close to window zones. Hence, the external light shelf in the sustainable design is more efficient to control the brightness issues and glaring problems. As a result, the significance of this research presented that, despite the fact that the constrained achievement is obtained when light shelf is used under over-cast sky conditions; light shelf external ( $\left(7^{\prime}\right)$ at an angle of $20^{\circ}$ is observed as the utmost appropriate selection. Based on the above findings it is concluded that external light shelf at a height of 7' enriched the daylight level nearly $11.5 \%$ in $21^{\text {st }}$ June and $10.6 \%$ in $21^{\text {st }}$ December as compared to without light shelves within the study space. Furthermore, the shaded range is decreased by the rise in the angle of Light shelf that have a tendency to accelerate the inside average lighting. On the other hand, the height and position of light shelves has a greater impact on the performance of light shelf.

\section{ACKNOWLEDGMENT}

The authors wish to thank all the kind people around who helped in making this research possible. 
Especially the Authors thanks to Dr. Anis Ahmad, Department of Architecture, Punjab University, Lahore, Pakistan, who helped us a lot in completing this work. Authors are also thankful to the Department of Architectural Engineering \& Design, University of Engineering \& Technology, Lahore, Pakistan, for providing information regarding the following research.

\section{REFERENCES}

[1] Khan, M.A., Arif, S., and Alamgir, K., "Comparison of Buildings Thermal Loads against Building Orientations for Sustainable Housing in Pakistan", Mehran University Research Journal of Engineering and Technology, Vol. 31, pp. 431-436.

[2] İnan, T., "An Investigation on Daylighting Performance in Educational Institutions", Structural Survey, Vol. 31, No. 2, pp. 121-138, 2013.

[3] Lee, H., Park, S., and Seo, J., "Development and Performance Evaluation of Light Shelves Using Width-Adjustable Reflectors", Advances in Civil Engineering, pp.1-9, 2018.

[4] Ponmalar, V., and Ramesh, B., "Energy Efficient Building Design and Estimation of Energy Savings from Daylighting in Chennai", Energy Engineering, Vol. 111, No. 4, pp. 59-80, 2014.

[5] Al-Khatatbeh, B.J., and Ma'bdeh, S.N., "Improving Visual Comfort and Energy Efficiency in existing Classrooms Using Passive Daylighting Techniques", Energy Procedia, Vol. 136, pp. 102-108, 2017.

[6] Siddique, S., Arif, S., and Khan, M.A., "Optimum Insulation Thickness for Walls and Roofs for Reducing Peak Cooling Loads in Residential Buildings in Lahore", Mehran University Research Journal of Engineering and Technology, Vol. 35, No. 4, Jamshoro, Pakistan, October, 2016.

[7] Moreno, P., Beatriz, M., and Labarca, C.Y. "Methodology for Assessing Daylighting Design Strategies in Classroom with a
Climate-Based Method", Sustainability, Vol. 7, No. 1, pp. 880-897, 2015.

[8] Bangali, J.A., and Arvind, D.S., "Simulation and Development of Lighting Control System Using Daylight for Corridor of a Building", Simulation, Vol. 1, No. 12, 2014.

[9] Kumar, S.P., and Vishwas, M., "Lighting Control Strategy for Energy Efficient Office Lighting System Design", Energy and Buildings, Vol. 66, pp. 329-337, 2013.

[10] Yousuf, S., Alamgir, A., Afzal, M., Maqsood, S., and Arif, M.S., "Evaluation of Daylight Intensity for Sustainability in Residential Buildings in Cantonment Cottages Multan", Mehran University Research Journal of Engineering and Technology, Vol. 36, No. 3, pp. 597-608, Jamshoro, Pakistan, July, 2017.

[11] Javier, G., and Fiorito, F., "Daylight Design of Office Buildings: Optimization of External Solar Shadings by Using Combined Simulation Methods", Buildings, Vol. 5, No. 2, pp. 560-580, 2015.

[12] Oh, S., Lee, H., and Kim, Y., "Basic Research on Performance Evaluation of Light Shelf Applying Curvature", Advanced Science and Technology Letters, Vol. 47, pp. 30-33, 2014.

[14] Cüneyt, K., and Esen, O., "Efficiency of Light Shelves According to Latitudes in Office Buildings", Gazi University Journal of Science, Vol. 29, No. 4, pp. 711-721, 2016.

[15] Suhail, Z., "The Influence of Selected Design Parameters on the Performance of Light Shelves under Overcast Conditions", Architecture Research, Vol. 5, No. 4, pp. 113-120, 2015.

[16] El-Darwish, I.I., and El-Gendy, R.A., "The Role of Fenestration in Promoting Daylight Performance: The Mosques of Alexandria Since the 19th Century", Alexandria Engineering Journal, Vol. 55, No. 4, pp. 3185-3193, 2016.

[17] Heang, W.L., Hoo, S.J., and Seong, K.Y., "A Preliminary Study on Daylighting Performance Evaluation of Light Shelf based on the Inclined Ceiling during Winter Solstice", Architecture and Civil Engineering, Vol. 47, pp. 46-49, 2014. 
[18] Hu, J., Du, J., and Place, W., "The Assessment of Advanced Daylighting Systems in Multi-Story Office Buildings Using a Dynamic Method", World Renewable Energy Congress, Linköping; Sweden. No. 057, Linköping University Electronic Press, Sweden, 2011.

[19] Lee, H., Kim, S., and Seo, J., "Evaluation of a Light Shelf Based on Energy Consumption for Lighting and Air Conditioning", Indoor and Built Environment, Vol. 27, No. 10, pp. 1405-1414, 2018.

[20] Chien, S.-C., and Tseng, K.J., "Assessment of Climate-Based Daylight Performance in Tropical Office Buildings: A Case Study", International Journal of Low-Carbon Technologies, Vol. 9, No. 2, pp. 100-108, 2014.

[21] Nair, M.G., Ramamurthy, K., and Ganesan, A.R., "Classification of Indoor Daylight Enhancement Systems", Lighting Research and Technology, Vol. 46, No. 3, pp. 245-267, 2014.

[22] Moazzeni, M.H., and Zahra, G., "Investigating the Influence of Light Shelf Geometry Parameters on Daylight Performance and Visual Comfort: A Case Study of Educational Space in Tehran, Iran", Buildings, Vol. 6, No. 3, pp. 26, 2016.

[23] Lee, H., Seo, J., and Kim, S., "Improvement of Light-Shelf Performance through the Use of a Diffusion Sheet", Building and Environment, Vol. 144, pp. 248-258, 2018.

[24] Lee, H., Choi, C.H., and Sung, M., "Development of a Dimming Lighting Control System Using General Illumination and Location-Awareness Technology", Energies, Vol. 11, No. 11, pp. 2999, 2018. 